Article

\title{
Cobalt Nanoparticles on Plasma-Controlled Nitrogen-Doped Carbon as High-Performance ORR Electrocatalyst for Primary Zn-Air Battery
}

\author{
Seonghee Kim ${ }^{1}$, Hyun Park ${ }^{2}$ and Oi Lun $\mathrm{Li}^{1, * \mathbb{C}}$ \\ 1 School of Materials Science and Engineering, Pusan National University, Busan 46241, Korea; \\ ksh09290@pusan.ac.kr \\ 2 Department of Naval Architecture and Ocean Engineering, Pusan National University, Busan 46241, Korea; \\ hyunpark@pusan.ac.kr \\ * Correspondence: helenali@pusan.ac.kr
}

Received: 24 December 2019; Accepted: 26 January 2020; Published: 28 January 2020

\begin{abstract}
Metal-air batteries and fuel cells have attracted much attention as powerful candidates for a renewable energy conversion system for the last few decades. However, the high cost and low durability of platinum-based catalysts used to enhance sluggish oxygen reduction reaction (ORR) at air electrodes prevents its wide application to industry. In this work, we applied a plasma process to synthesize cobalt nanoparticles catalysts on nitrogen-doped carbon support with controllable quaternary- $\mathrm{N}$ and amino- $\mathrm{N}$ structure. In the electrochemical test, the quaternary- $\mathrm{N}$ and amino-N-doped carbon (Q-A)/Co catalyst with dominant quaternary-N and amino-N showed the best onset potential $\left(0.87 \mathrm{~V}\right.$ vs. RHE) and highest limiting current density $\left(-6.39 \mathrm{~mA} / \mathrm{cm}^{2}\right)$. Moreover, Q-A/Co was employed as the air catalyst of a primary zinc-air battery with comparable peak power density to a commercial $20 \mathrm{wt}$. $\mathrm{Pt} / \mathrm{C}$ catalyst with the same loading, as well as a stable galvanostatic discharge at $-20 \mathrm{~mA} / \mathrm{cm}^{2}$ for over $30,000 \mathrm{~s}$. With this result, we proposed the synergetic effect of transitional metal nanoparticles with controllable nitrogen-bonding can improve the catalytic activity of the catalyst, which provides a new strategy to develop a Pt-free ORR electrocatalyst.
\end{abstract}

Keywords: cobalt nanoparticles; nitrogen-doped carbon; highly durable electrocatalysts; Zn-air battery

\section{Introduction}

Eco-friendly energy devices such as metal-to-air batteries and fuel cells receive much attention, while the importance of air electrodes for oxygen reduction reactions is increasingly prominent. Mainly, air electrodes often require platinum catalysts to improve their slow oxygen reduction reaction (ORR). However, many studies are attempting to reduce the Pt content or entirely replace Pt due to its low durability, high price, and rarity. Among them, transition metal-based electrocatalysts have exhibited promising ORR performance in basic electrolytes and active research is being done in using these as $\mathrm{Pt}$ catalyst replacements [1-5]. Among the various transition metals, cobalt is the most widely used as an alternative catalyst material due to its decent oxygen reduction reaction activity, higher four-electron selectivity, high durability, and low price [6-9]. On the other hand, cobalt nanoparticles as single active sites supported on a pristine carbon matrix often exhibit low activity compared with platinum catalysts $[10,11]$. Thus, there are many attempting to improve the intrinsic activity of the catalysts. One of the most typical methods is to synthesize a catalyst using a heteroatom-doped carbon matrix $[12,13]$. Among them, nitrogen-doped (N-doped) carbon represents a far better performance compared with pristine carbon support [14-18]. The catalyst often shows relatively high catalytic performance in alkaline electrolytes. In the case of $\mathrm{N}$-doped carbon, nitrogen reduces the charge density of the nearby 
carbon atoms due to the differences in electronegativity of carbon and nitrogen [19]. Most recently, a few studies reported enhanced catalytic activity when combining cobalt nanoparticles with $\mathrm{N}$-doped carbon support, and some of their ORR activity might even be comparable to that of platinum-based catalysts [20-24].

To date, there are different arguments about how various types of nitrogen functional groups affect the activity of catalysts [25-34]. Chatterjee et al. reported nitrogen-carbon nano-ions with pyridinic-N and pyrrolic-N as dominant catalysts. The catalysts contained a nitrogen content of up to $7.5 \%$, and the author suggested that pyridinic-N worked as an active site for oxygen reduction with notably high activity [31]. On the other hand, Wang et al. found a correlation between the potential cycle and the diminishing concentration of quaternary- $\mathrm{N}$ in the catalyst. Based on the density functional theory (DFT) calculation and experimental results, quaternary-N displayed lower Gibbs free energy on the rate-liming step in the ORR reaction compared with pyridinic-N or pyrrolic- $\mathrm{N}$. The author claimed that quaternary- $\mathrm{N}$ was responsible for the ORR activity in $\mathrm{N}$-doped carbon [35]. Not only for single controlled C-N bonding, Yan also reported the synergetic effect of quaternary-Nand pyridinic-N-doping on the oxygen reduction reaction by using theoretical calculation [17]. After that, Ning et al. reported the synergetic effect of pyridinic-N and quaternary-N by measuring the transferable electrons of $\mathrm{N}$-doped carbon. They suggested that the kinetic current density of the ORR in alkaline media is depended on the ratio of pyridinic- $\mathrm{N}$ and quaternary- $\mathrm{N}$ [36]. Additionally, Li et al. reported another synergic effect of amino- $\mathrm{N}$ and quaternary-N on ORR, where the experimental results showed that dominant amino-N-doped carbon indicated a higher onset potential, and the incorporation of quaternary- $\mathrm{N}$ into amino- $\mathrm{N}$ improved the 4-electron reaction selectivity and limiting current density [28].

Recently, a great deal of research has been reported on the development of a heterogeneous atomic-doped carbon catalyst through bottom-up synthesis using heterocyclic compounds through liquid plasma engineering. The approach has many advantages, such as being conducted at room temperature and being able to synthesize a heterogeneous atomic-doped carbon catalyst simply by selecting different precursors [37-44]. On the other hand, due to the low thermal stability of amino-N, it is hard to retain amino-N on the carbon matrix by the conventional synthesis route [27]. Thus, we applied a low-temperature facile plasma synthesizing method to fabricate amino- $\mathrm{N}$ and quaternary-N selectively on carbon support by careful selection of the precursors. Although a few studies have reported on metal-free tunable N-doped carbon electrocatalysts and/or metal nanoparticles doped on $\mathrm{N}$-doped carbon, the synergic effect of transitional metal nanoparticles with precisely tunable amino- $\mathrm{N}$ and quaternary-N has rarely been reported.

In this study, we fabricated cobalt nanoparticles on a nitrogen-doped carbon catalyst through two heterocyclic compounds, quinoline and aniline, via plasma engineering. A pair of cobalt electrodes were applied as the precursor of metal nanoparticles, while quinoline and aniline were the sources of quaternary-N and amino-N, respectively, in the N-doped carbon support. Through XPS results, we can confirm that quaternary- $\mathrm{N}$ and amino- $\mathrm{N}$ are successfully retained within the carbon matrix from their corresponding precursors. Further, in the electrochemical performance test, cobalt nanoparticles supported on the mixture of quaternary-N and amino-N-doped carbon ((Q-A)/Co) had higher ORR onset potential and limiting current density than those of a single amino-N-doped carbon $(\mathrm{A} / \mathrm{Co})$ or quaternary-N-doped carbon $(\mathrm{Q} / \mathrm{Co})$ catalyst.

\section{Materials and Methods}

\subsection{Synthesis of Co-N/C Catalyst by a Plasma Process}

Plasma synthesis was performed between a pair of high purity transition cobalt electrodes (99.999\%, Nilaco Co., Ltd., Tokyo, Japan, diameter of $1 \mathrm{~mm}$ ) inside an organic solution of aniline (A-Co), quinolone (Q-Co), and aniline-quinoline 1:1: mixed solution (Quinoline, Aniline, $>99 \%$, Junsei Chemical Co., Ltd., Tokyo, Japan) using a bipolar pulse power supply (MPP-HV02, KURITA, Kyoto, 
Japan). The plasma was discharged at a voltage of $\sim 4 \mathrm{kV}$, a frequency of $50 \mathrm{kHz}$, and a pulse width of $1.0 \mu$ s. Stable plasma was discharged for $30 \mathrm{~min}$ to obtain cobalt nanoparticles/N-doped carbon (Co-N/C). The solution was filtered using a $\phi 55 \mathrm{~mm}$ polytetrafluoroethylene filter, and the resulting filtered carbon powder samples were dried in an oven for $10 \mathrm{~h}$ at $80^{\circ} \mathrm{C}$, then heated at $700{ }^{\circ} \mathrm{C}$ for $1 \mathrm{~h}$ with $1.0 \mathrm{cc} / \mathrm{min}$ nitrogen atmosphere to improve their electrical conductivity. The schematic of the plasma synthesis is illustrated in Figure 1.

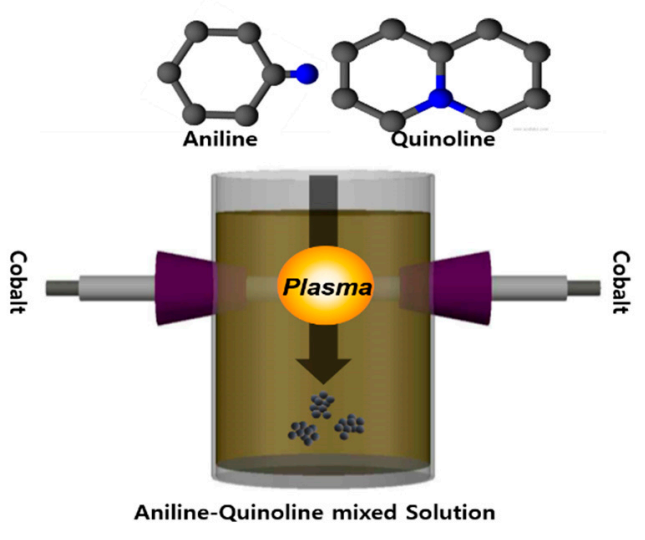

(a)

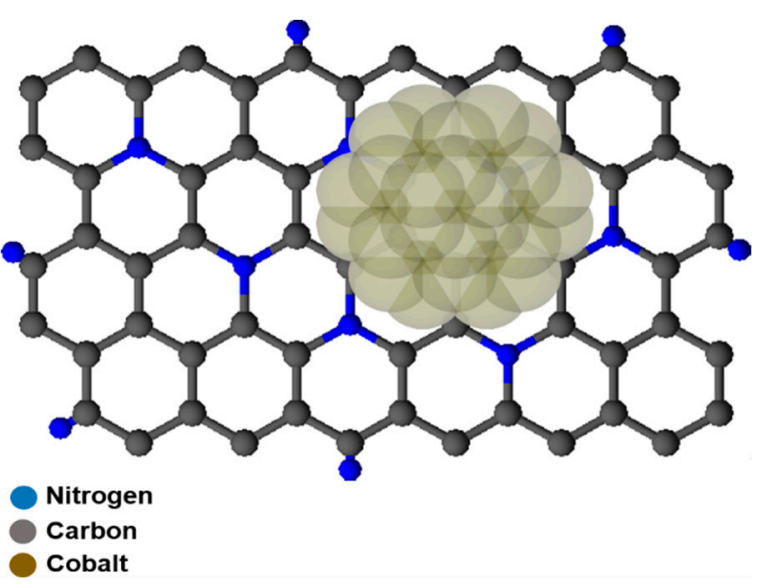

(b)

Figure 1. (a) Schematic illustration of the solution plasma process and synthesis of the cobalt nanoparticles/N-doped carbon (Co-N/C) catalyst. (b) Structure of the N-doped carbon catalyst.

\subsection{Structure and Chemical Composition Analysis}

The nitrogen absorption-desorption method (BET, Brunauer Emmett Teller; Shimadzu, TriStar-II 3020, Tokyo, Japan) was used for analyzing the surface area, pore volume, and pore diameter of the various $\mathrm{Co}-\mathrm{N} / \mathrm{C}$ catalysts. For morphology and chemical composition analysis, the synthesized carbon samples were characterized using scanning electron microscopy (SEM; JEOL, JSM-7100F, Tokyo, Japan), X-ray diffraction (XRD; Rigaku, Ultima IV, Tokyo, Japan), and X-ray photoelectron spectroscopy (XPS; JEOL, JPS-9010MC, Tokyo, Japan).

\subsection{Electrochemical Measurements}

An electrochemical analyzer (Biologic, VSP, Grenoble, France) was used to analyze the ORR electrochemical properties of the synthesized cobalt-nitrogen-doped carbon. The catalyst ink for the electrochemical analysis was made by adding $4 \mathrm{mg}$ of well-ground Co-N/C-doped carbon catalysts into a mixture composed of $480 \mu \mathrm{L}$ of distilled water, $480 \mu \mathrm{L}$ of ethanol, and $40 \mu \mathrm{L}$ of Nafion ${ }^{\circledR} 117$ Solution that was then ultrasonicated for $30 \mathrm{~min}$. A total of $800 \mu \mathrm{g} / \mathrm{cm}^{2}$ of well-dispersed catalyst was applied on a well-polished glass carbon (GC) disk (diameter: $4 \mathrm{~mm}$ ) electrode (working electrode), where a platinum coil and $\mathrm{Hg} / \mathrm{HgO}(1 \mathrm{M} \mathrm{NaOH})$ were used as the counter and reference electrodes, respectively. After the three-electrode cell was prepared, ORR activity was measured by linear sweep voltammetry (LSV) in $\mathrm{O}_{2}$ saturated $0.1 \mathrm{M} \mathrm{KOH}$ with a scan rate of $5 \mathrm{mV} / \mathrm{s}$ and rotating speed of $1600 \mathrm{rpm}$, between a potential range of 0.2 to $1.2 \mathrm{~V}$ vs. RHE. Chronoamperometry (CA) was conducted at $0.6 \mathrm{~V}$ vs. RHE for $30,000 \mathrm{~s}$. In order to investigate the cycle durability of the synthesized catalysts, cyclic voltammetry (CV) was conducted at $50 \mathrm{mV} / \mathrm{s}$ for 3000 cycles between a potential range of 0.4 and $1.0 \mathrm{~V}$ vs. RHE. The kinetic current of the prepared electrocatalyst was calculated by a rotation rind disk electrode (RRDE). Where $i_{d}$ is disk current, $i_{r}$ is ring current, and $C_{e}$ is collection efficiency (0.42) [45]:

$$
\text { Electron transfer number }(\mathrm{n})=4 *\left(i d /\left(i d+\left(\frac{i r}{C e}\right)\right)\right.
$$




$$
\mathrm{H}_{2} \mathrm{O}_{2} \text { yielding }(\%)=2 *\left(\frac{\frac{i r}{\mathrm{Ce}}}{\mathrm{Id}+\left(\frac{i r}{\mathrm{Ce}}\right)}\right) * 100
$$

\subsection{Primary Zn-Air Battery Measurement}

The home-made $\mathrm{Zn}$-air battery was assembled with the as-prepared catalysts and loaded on a gas diffusion layer electrode, with a $\mathrm{Zn}$ foil as the metal electrode, and $6 \mathrm{M} \mathrm{KOH}+0.2 \mathrm{M} \mathrm{ZnCl}_{2}$ as the electrolyte. For comparison, a benchmark catalyst $(20 \mathrm{wt} . \% \mathrm{Pt} / \mathrm{C})$ was also measured as the oxygen electrocatalyst. The catalyst ink (same as electrochemical ORR measurement) were well-suspended and dropped onto one face of carbon paper, with a mass loading of $1 \mathrm{mg} / \mathrm{cm}^{-2}$. The power density was measured at $10 \mathrm{mV} / \mathrm{s}$ from OCV to 0.4 and discharge stability of the sample was measured by discharging at $-20 \mathrm{~mA} / \mathrm{cm}^{2}$ for $30,000 \mathrm{~s}$.

\section{Results}

\subsection{Properties of Co Nanoparticles/N-Doped Carbon Catalyst}

The SEM images of $\mathrm{Q}-\mathrm{A} / \mathrm{Co}, \mathrm{A} / \mathrm{Co}$, and $\mathrm{Q} / \mathrm{Co}$ are shown in Figure 2a-c. The three electrocatalysts exhibited very similar morphology, and carbon spherical nanoparticles were heavily agglomerated. There were no obvious structural differences from applying various types of nitrogen-carbon precursors during the plasma process. Figure 3 demonstrates the low resolution SEM images with EDS elemental mapping for Q-A/Co, Table S1 summarizes the atomic percentage of each element. It was found that nitrogen from the heterocyclic compound precursors (aniline and quinoline) was successfully retained with a high concentration of around $5 \%$ within the carbon matrix. Although the percentage of Co (at.\%) was quite small (0.01-0.03\%), cobalt nanoparticles formed by electrode sputtering during the plasma process were uniformly deposited on the synthesized carbon matrix (Figure 3c).

(a) $\mathrm{Q}-\mathrm{A} / \mathrm{CO}$

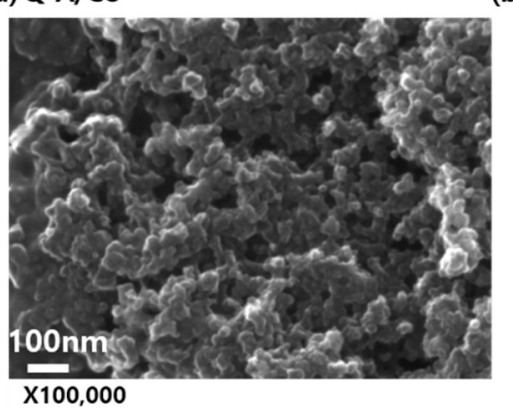

(b) $\mathrm{A} / \mathrm{Co}$

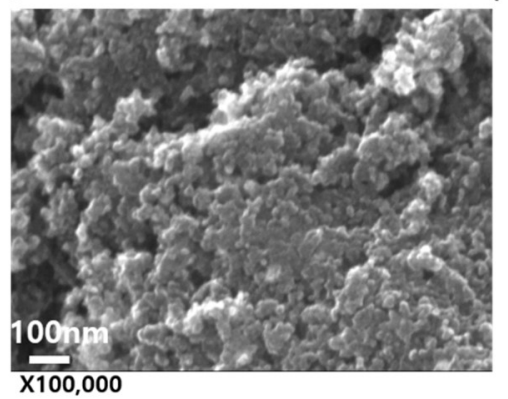

(c) $\mathrm{Q} / \mathrm{Co}$

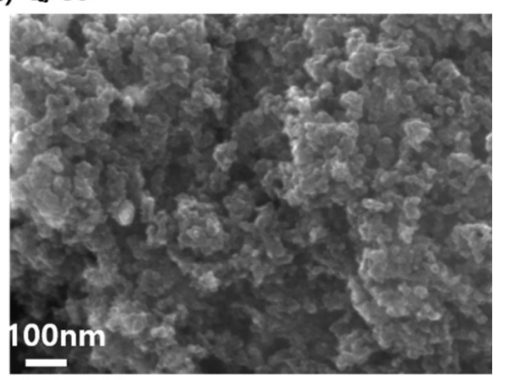

$\mathrm{X} 100,000$

Figure 2. SEM images of the (a) quaternary-N and amino-N-doped carbon ( $\mathrm{Q}-\mathrm{A} / \mathrm{Co}$ ), (b) amino-N-doped carbon $(\mathrm{A} / \mathrm{Co})$, and $(\mathrm{c})$ quaternary-N-doped carbon $(\mathrm{Q} / \mathrm{Co})$ catalysts.

Figure 4 and Table 1 summarize the porous structure of the synthesized N-doped carbon obtained from the $\mathrm{N}_{2}$ adsorption-desorption method. The BET isotherm linear plot in Figure 4a confirms that all synthesized N-doped carbon had a meso-macro porous structure from the hysteresis graph. This is coming from the interparticle voids between the primary carbon particles in the usual solution plasma method synthesized carbon [46]. The BET surface areas of Q-A/Co, A/Co, and Q/Co were 211.1, 210.2, and $206.2 \mathrm{~m}^{2} / \mathrm{g}$, respectively. This result implies that the porous and structural properties of synthesized $\mathrm{Co}-\mathrm{N}$-doped carbon are not affected by the original precursor. In Figure $4 \mathrm{~b}, \mathrm{Q}-\mathrm{A} / \mathrm{Co}$ exhibits a slightly higher pore volume of $0.67 \mathrm{~cm}^{3} / \mathrm{g}$ and has mainly mesopores with an average diameter of $10.1 \mathrm{~nm}$. To confirm the crystalline structure of the deposited cobalt particle, XRD analysis in Figure 5 clearly indicates pure cobalt metal peaks $\left(\mathrm{Co}^{0}\right)$ at $44^{\circ}\left([110], 52^{\circ}([200])\right.$, and $76^{\circ}([220])$. Regardless of the liquid precursor, the composition of the cobalt nanoparticles is identical with similar crystallinity. Combined with the EDS picture and XRD profile, it is clear that the cobalt nanoparticles in their pristine form are successfully fabricated through the plasma process and incorporated into N-doped carbon support. 
(a)

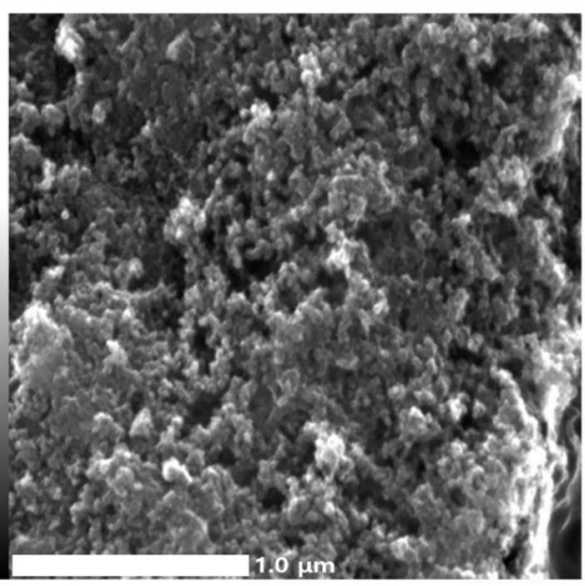

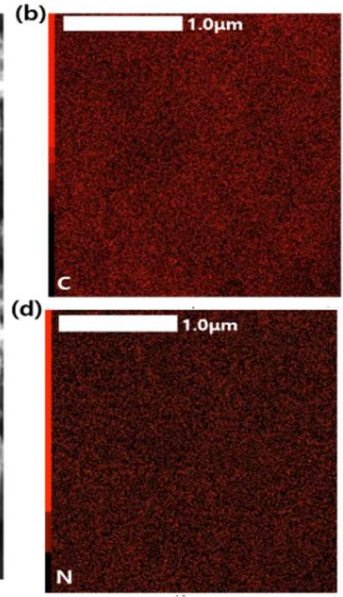

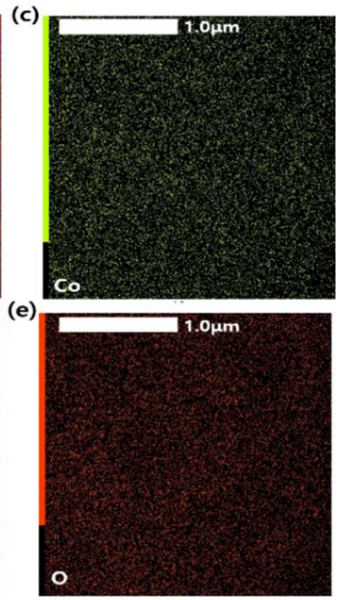

Figure 3. (a) SEM image of the Q-A/Co catalyst. (b-e) EDS mapping of the synthesized Q-A/Co catalyst: (b) carbon, (c) cobalt, (d) nitrogen, (e) oxygen.
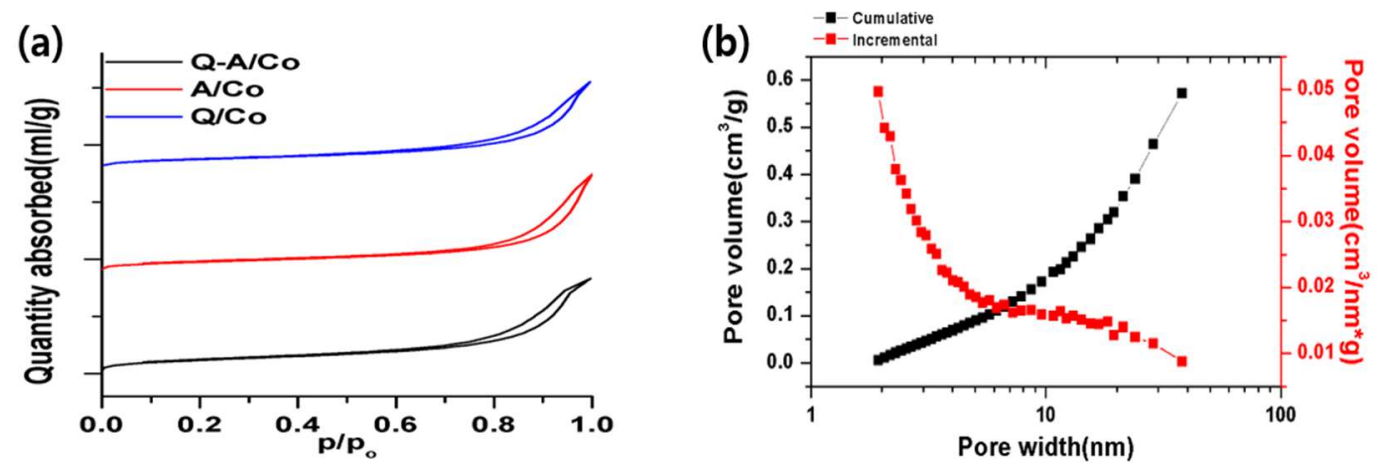

Figure 4. (a) BET isotherm linear plot of the three types of synthesized $\mathrm{N}$-doped carbon. (b) Barrett-Joyner-Halenda (BJH) adsorption pore distribution of Q-A/Co.

Table 1. Textural parameters of Q/A-Co derived from the N2 adsorption-desorption isotherms.

\begin{tabular}{cccc}
\hline BET Surface Area & $\begin{array}{c}\text { BJH Adsorption } \\
\text { Pore Volume }\end{array}$ & $\begin{array}{c}\text { BJH Adsorption } \\
\text { Average Pore Width }\end{array}$ \\
\hline Q-A/Co & $211.1 \mathrm{~m}^{2} / \mathrm{g}$ & $0.6711 \mathrm{~cm}^{3} / \mathrm{g}$ & $10.1 \mathrm{~nm}$ \\
\hline A/Co & $210.2 \mathrm{~m}^{2} / \mathrm{g}$ & $0.6708 \mathrm{~cm}^{3} / \mathrm{g}$ & $13.08 \mathrm{~nm}$ \\
\hline Q/Co & $206.2 \mathrm{~m}^{2} / \mathrm{g}$ & $0.5871 \mathrm{~cm}^{3} / \mathrm{g}$ & $15.3 \mathrm{~nm}$ \\
\hline
\end{tabular}

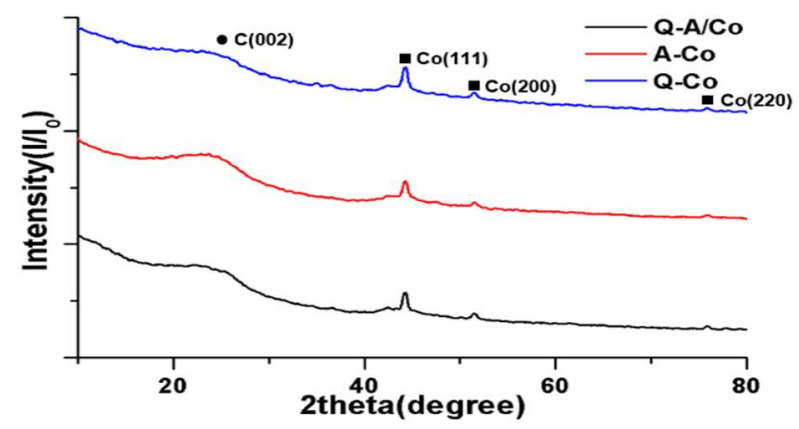

Figure 5. XRD patterns obtained for metal cobalt-N doped carbon. 


\subsection{Chemical Bonding States of Co Nanoparticles/N-Doped Carbon Catalyst}

In order to analyze and understand the effect of nitrogen functional groups on ORR catalytic activity, we applied XPS to figure out the surface nitrogen-carbon bonding states in detail. First, we can confirm that nitrogen is successfully doped into the carbon matrix by the presence of $\mathrm{C}-\mathrm{N}$ bonding in all synthesized samples from C1s XPS spectra in Figure 6a-c. In order to identify the types of C-N bonding, N1s narrow spectra of $\mathrm{Q}-\mathrm{A} / \mathrm{Co}, \mathrm{A} / \mathrm{Co}$, and $\mathrm{Q} / \mathrm{Co}$ are demonstrated in the corresponding Figure $6 \mathrm{~d}-\mathrm{f}$. As a reference, the binding energy of amino- $\mathrm{N}$ is around $399.4-399.6 \mathrm{eV}$ and quaternary- $\mathrm{N}$ is around 401.1-401.5 eV [47]. $\mathrm{A} / \mathrm{Co}$, which was synthesized from the aniline precursor, shows a highest amino-N peak of $35 \%$. Additionally, $\mathrm{Q} / \mathrm{Co}$ fabricated from the quinoline precursor shows a dominant quaternary-N peak of $32 \%$. For Q-A/Co, which was synthesized from a mixed aniline and quinoline solution, two major peaks for quaternary-N (30\%) and amino- $\mathrm{N}(31 \%)$ are present equally. From the above XPS results, it is clear that $\mathrm{C}-\mathrm{N}$ bonding is retained from the heterocyclic compound precursor, and plasma engineering is a facile route to control various types of nitrogen-carbon bonding by choosing the corresponding single or multiple $\mathrm{C}-\mathrm{N}$ precursors. The relative percentages of nitrogen bonding states of three Co-N-doped catalysts are summarized in Table 2.
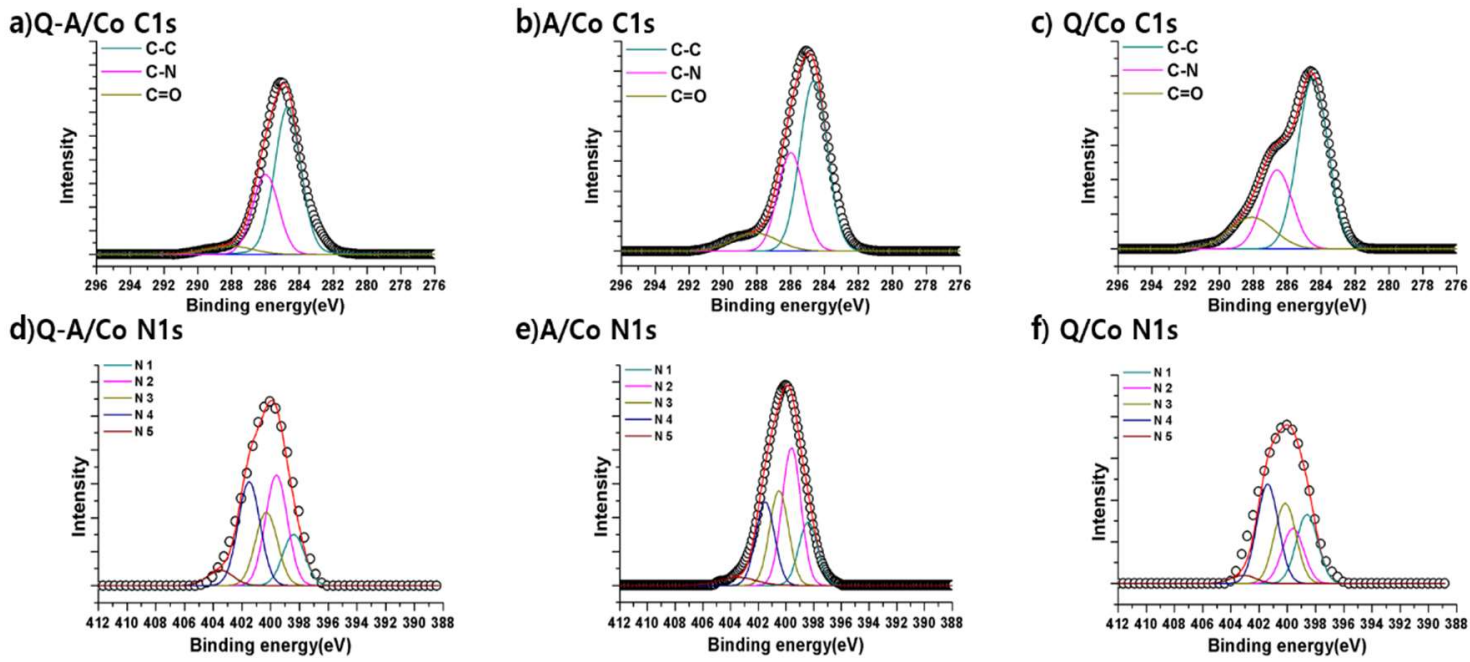

Figure 6. (a-c) High-resolution C 1s XPS spectra with peak deconvolution of Co-N/C. (d-f) N 1s XPS spectra with peak deconvolution of Co-N/C.

Table 2. Nitrogen bonding states of three Co-N-doped catalysts from the deconvolution of N 1s spectra.

\begin{tabular}{|c|c|c|c|c|}
\hline \multirow{2}{*}{ Bonding } & \multirow{2}{*}{ Binding Energy } & Q-A/Co & A-Co & Q-Co \\
\hline & & \multicolumn{3}{|c|}{ Relative Percentage (\%) } \\
\hline N1(Pyridinic-N) & $398.4-398.6 \mathrm{eV}$ & 14 & 16 & 22 \\
\hline N2(Amino-N) & $399.4-399.6 \mathrm{eV}$ & 31 & 35 & 18 \\
\hline N3(Pyrrolic-N) & $400.1-400.3 \mathrm{eV}$ & 20 & 24 & 25 \\
\hline N4(Quaternary-N) & $401.1-401.5 \mathrm{eV}$ & 30 & 21 & 32 \\
\hline N5(Oxide-N) & $403.3-403.7 \mathrm{eV}$ & 5 & 4 & 3 \\
\hline
\end{tabular}

\subsection{Electrochemical Properties of Co Nanoparticles/N-Doped Carbon Catalyst}

Figure 7a-d shows the electrochemical ORR catalytic activity of synthesized Co-N-doped carbon in $0.1 \mathrm{M} \mathrm{KOH}$. In the polarization curve, $\mathrm{A} / \mathrm{Co}$ with dominant amino- $\mathrm{N}$ demonstrates a slightly higher onset potential ( $0.85 \mathrm{~V}$ vs. RHE) than that of the $\mathrm{Q} / \mathrm{Co}(0.84 \mathrm{~V}$ vs. RHE). Figure $7 \mathrm{~b}$ demonstrates a lower Tafel-slope of Q/Co $(67 \mathrm{mV} / \mathrm{dec})$ and Q-A/Co $(78 \mathrm{mV} / \mathrm{dec})$ compared with that of $\mathrm{A} / \mathrm{Co}(89 \mathrm{mV} / \mathrm{dec})$, which indicates that quaternary-N doping can improve the ORR reaction kinetics. Figure S1a-c 
further evaluated the CV curves of each electrocatalyst with a scan rate of $10-80 \mathrm{mV} / \mathrm{s}$, and the double layer capacitance $\left(\mathrm{C}_{d l}\right)$ values are derived from each $\mathrm{CV}$ based on the equation $\mathrm{C}_{d l}=\frac{d(\Delta j)}{2 d(V b)}$, where $\mathrm{V} b$ is the scan rate (Figure S1). The electrochemically active surface areas (ECSA) are calculated by $E C S A=C_{d l} / C s$, of which $C_{s}$ is the specific capacitance of a flat surface with $1 \mathrm{~cm}^{2}$ of surface area, and the rugosity can be estimated from ECSA/geometric surface area $\left(0.1256 \mathrm{~cm}^{2}\right)[48,49]$. The calculated $\mathrm{C}_{d l}$ values of $\mathrm{A} / \mathrm{Co}, \mathrm{Q} / \mathrm{Co}$, and $\mathrm{Q}-\mathrm{A} / \mathrm{Co}$ were $14 \mathrm{mF} / \mathrm{cm}^{2}, 14 \mathrm{mF} / \mathrm{cm}^{2}$, and $11 \mathrm{mF} / \mathrm{cm}^{2}$, respectively. Although ESCA, of all synthesized catalysts, exhibited a similar value of $11-14 \mathrm{mF} / \mathrm{cm}^{2}$, the limiting current density of the $\mathrm{Q} / \mathrm{Co}$ at $0.6 \mathrm{~V}$ vs. RHE $\left(-6.41 \mathrm{~mA} / \mathrm{cm}^{2}\right)$ was much higher than that of the $\mathrm{A} / \mathrm{Co}$ $\left(-5.17 \mathrm{~mA} / \mathrm{cm}^{2}\right)$. This result clearly implies that amino-N has a positive effect on the onset potential, whereas quaternary- $\mathrm{N}$ improves the reaction kinetics, both of which are similar to previously reported findings $[28,50]$. Interestingly, $\mathrm{Q}-\mathrm{A} / \mathrm{Co}$ with both dominant amino-N and quaternary-N shows certain differences in ORR activity compared with single amino-N-doped carbon or quaternary-N-doped carbon. The Q-A/Co exhibits better onset potential ( $0.87 \mathrm{~V}$ vs. RHE) and limiting current density $\left(-6.27 \mathrm{~mA} / \mathrm{cm}^{2}\right)$, which is quite comparable to a commercial $20 \mathrm{wt} . \% \mathrm{Pt} / \mathrm{C}$ catalyst. $(0.95 \mathrm{~V}$ vs. RHE and $-5.43 \mathrm{~mA} / \mathrm{cm}^{2}$ ). In reaction selectivity results based on the electron transfer number calculation in Figure S2, Q-A/Co shows the higher 4 e- selectivity of 3.91 compared with those of Q/Co and A/Co ( 3.8). The above findings prove the synergetic effect of amino- $\mathrm{N}$ and quaternary- $\mathrm{N}$ on ORR activities. In the durability test as displayed in Figure 7c,d, the onset ORR potential of Q-A/Co and $20 \mathrm{wt} . \% \mathrm{Pt} / \mathrm{C}$ shift negatively by $10 \mathrm{mV}$ and $20 \mathrm{mV}$, respectively, after 3000 cycles. Moreover, the relative current density of Q-A/Co reduces by merely $9 \%$ while $20 \mathrm{wt} . \% \mathrm{Pt} / \mathrm{C}$ decreases by $16 \%$ after $30,000 \mathrm{~s}$ at $0.6 \mathrm{~V}$ vs. RHE. Both experimental results confirmed that the amino- $\mathrm{N}$ and quaternary- $\mathrm{N}$ are incorporated into the carbon matrix with high stability. The detailed electrochemical catalytic activity of Co-N-doped carbon and 20wt.\% Pt/C are summarized in Table 3.

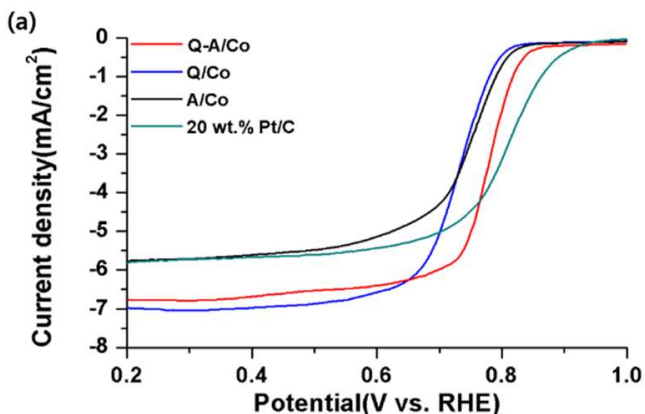

(c)

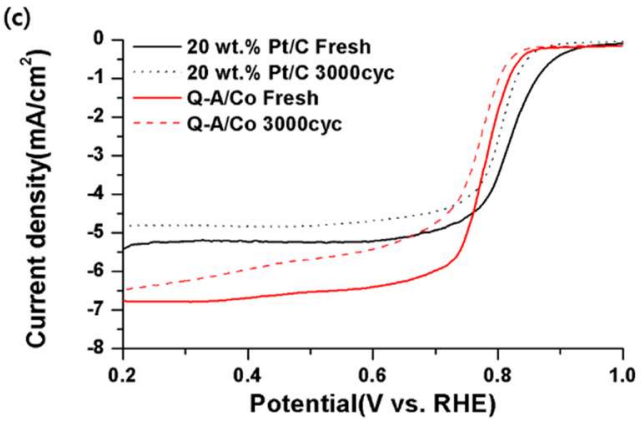

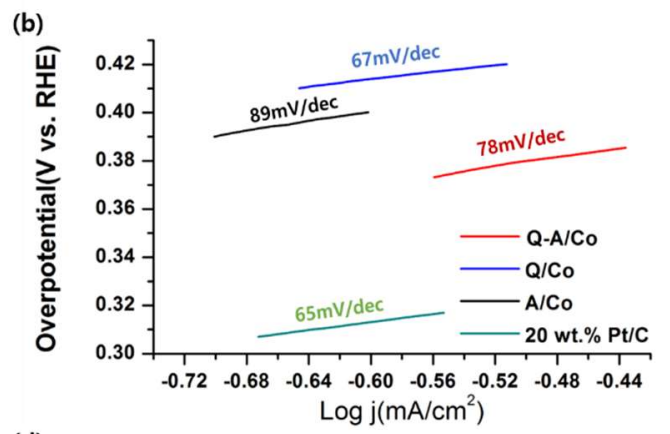

(d)

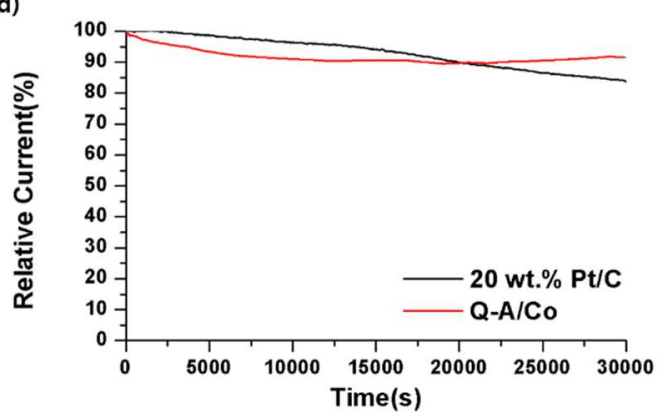

Figure 7. (a) Linear sweep voltammetry (LSV) curve of Co-N-doped carbon and $20 \mathrm{wt} . \% \mathrm{Pt} / \mathrm{C}$ at $5 \mathrm{mV} / \mathrm{s}$ in $\mathrm{O}_{2}$ saturated $0.1 \mathrm{M} \mathrm{KOH}$ in rotation speed $1600 \mathrm{rpm}$. (b) Correlated Tafel slope from each LSV curve. (c) Cycle durability of Q-A/Co and $20 \mathrm{wt} . \% \mathrm{Pt} / \mathrm{C}$ after 3000 cycles. (d) Chronoamperometry (CA) of $\mathrm{Q}-\mathrm{A} / \mathrm{Co}$ and 20 wt.\% Pt/C at $0.6 \mathrm{~V}$ vs. RHE. 
Table 3. Summary of the electrochemical catalytic activity of Co-N-doped carbon and $20 \mathrm{wt} . \% \mathrm{Pt} / \mathrm{C}$.

\begin{tabular}{ccccc}
\hline & Q-A/Co & Q/Co & A/Co & 20 wt.\% Pt/C \\
\hline Onset Potential & $0.87 \mathrm{~V}$ vs. RHE & $0.84 \mathrm{~V}$ vs. RHE & $0.85 \mathrm{~V}$ vs. RHE & $0.95 \mathrm{~V}$ vs. RHE \\
\hline $\begin{array}{c}\text { Potential } \\
\text { at }-3 \mathrm{~mA} / \mathrm{cm}^{2}\end{array}$ & $0.78 \mathrm{~V}$ vs. RHE & $0.74 \mathrm{~V}$ vs. RHE & $0.74 \mathrm{~V}$ vs. RHE & $0.81 \mathrm{~V}$ vs. RHE \\
\hline $\begin{array}{c}\text { Current density } \\
\text { At 0.6 V vs. RHE }\end{array}$ & $-6.27 \mathrm{~mA} / \mathrm{cm}^{2}$ & $-6.41 \mathrm{~mA} / \mathrm{cm}^{2}$ & $-5.17 \mathrm{~mA} / \mathrm{cm}^{2}$ & $-5.43 \mathrm{~mA} / \mathrm{cm}^{2}$ \\
\hline $\begin{array}{c}\text { Potential } \\
\text { at }-3 \mathrm{~mA} / \mathrm{cm}^{2}\end{array}$ & $0.77 \mathrm{~V}$ vs. RHE & - & - & \\
$\begin{array}{c}\text { After 3000 cycles } \\
\text { Figure 7c }\end{array}$ & & & & $0.79 \mathrm{~V} \mathrm{vs.} \mathrm{RHE}$ \\
\hline $\begin{array}{c}\text { Current density } \\
\text { After 3000 cycles } \\
\text { Figure 7d }\end{array}$ & $9 \%$ decrease & - & - & $16 \%$ decrease \\
\hline
\end{tabular}

\subsection{Primary Zn-Air Battery Test of Co Nanoparticles/N-Doped Carbon Catalyst ( $Q-A / C o)$}

Since Q-A/Co outperformed other as-synthesized electrocatalysts, it was further applied as the air cathode in a home-made primary aqueous $\mathrm{Zn}$-Air battery cell, in order to examine its performance in a practical application. In open circuit voltage, the Q-A/Co catalyst exhibited an open-current voltage $(\mathrm{OCV})$ of $1.43 \mathrm{~V}$, which is only slightly lower than that of $20 \mathrm{wt} . \% \mathrm{Pt} / \mathrm{C}(1.49 \mathrm{~V})$. On the other hand, the peak power density of Q-A/Co $\left(87 \mathrm{~mW} / \mathrm{cm}^{2}\right)$ is almost similar to the $\mathrm{Pt} / \mathrm{C}\left(89 \mathrm{~mW} / \mathrm{cm}^{2}\right)$ due to the higher discharge current density (Figure 8b). Although the step-voltage discharge of Q-A/Co (Figure 8c) shows lower voltage in the low current density range between 1 and $20 \mathrm{~mA} / \mathrm{cm}^{2}, \mathrm{Q}-\mathrm{A} / \mathrm{Co}$ works comparably to the commercial $20 \mathrm{wt} . \% \mathrm{Pt} / \mathrm{C}$ catalyst in a higher current density region above $50 \mathrm{~mA} / \mathrm{cm}^{2}$. During the galvanostatic discharge at $-20 \mathrm{~mA} / \mathrm{cm}^{2}$, the Q-A/Co catalyst displays a stable discharge for 30,000 s (Figure 8d). Based on the Zn-air battery test, Q-A/Co is a potential noble-free ORR catalyst to replace expensive noble $\mathrm{Pt} / \mathrm{C}$ in primary $\mathrm{Zn}$-air batteries with the high peak power density and durable discharge performance.

(a)

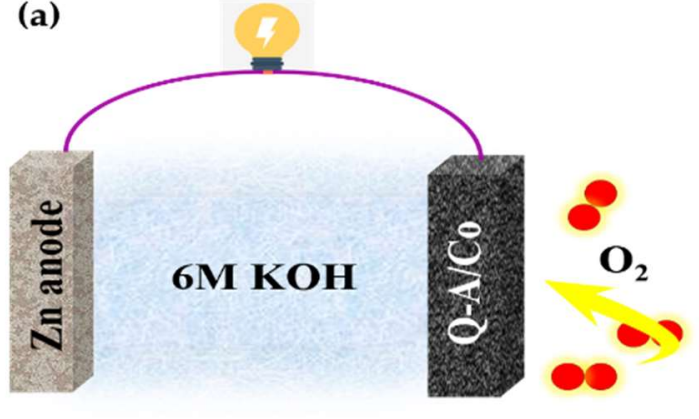

(c)

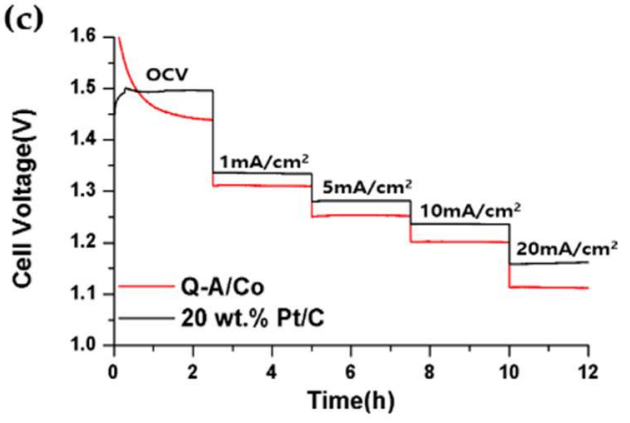

(b)

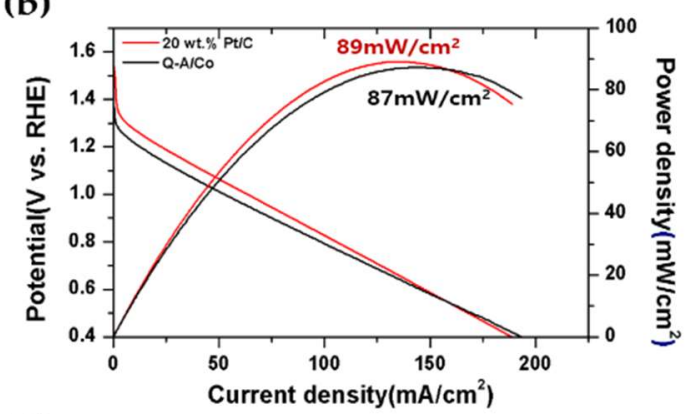

(d)

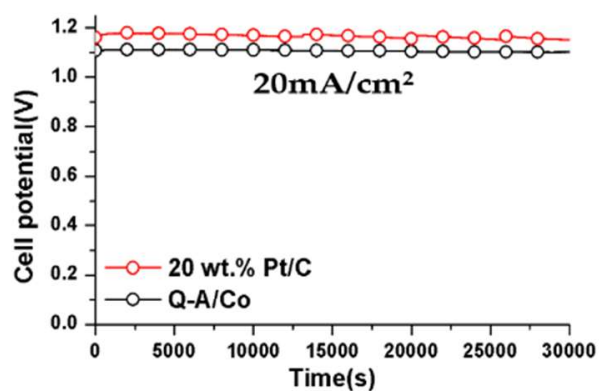

Figure 8. (a) Graph for the home-made Zn-air battery. (b) Discharge power density of Q-A/Co at $10 \mathrm{mV} / \mathrm{s}$. (c) OCV and step voltage of Q-A/Co. (d) Discharge stability of Q-A/Co at $20 \mathrm{~mA} / \mathrm{cm}^{2}$. 


\section{Conclusions}

Consequently, in this study, cobalt with dominant amino-N- and quaternary-N-doped carbon was synthesized through a plasma process. Both EDS and XRD results indicated that Co particles were deposited on the carbon matrix with nitrogen. From the XPS surface analysis, Q-A/Co exhibited both major amino-N and quaternary-N peaks evenly. This result clearly indicated that aniline and quinoline precursors can be applicable as selective N-C bonding precursors. From the electrocatalytic activity measurement, we confirmed that amino- $\mathrm{N}$ had a positive effect on ORR onset potential, whereas quaternary-N improved the limit current density, as reported. In particular, the combination of amino- $\mathrm{N}$ and quaternary-N provided a synergetic effect to better the onset potential and limit current density. Q-A/Co displayed a relatively high catalytic activity in terms of onset potential ( $0.87 \mathrm{~V}$ vs. RHE) and limit current density $\left(-6.39 \mathrm{~mA} / \mathrm{cm}^{2}\right)$, which is only slightly inferior to that of commercial $20 \mathrm{wt} . \% \mathrm{Pt} / \mathrm{C}$. In a primary $\mathrm{Zn}$-air electrode test, Q-A/Co further exhibited high potential from its high peak power density $\left(87 \mathrm{~mW} / \mathrm{cm}^{2}\right)$ and durable discharge performance. From the above results, we suggested that plasma engineering is a facile route to fabricate transition metal nanoparticles on selective amino- $\mathrm{N}$ and quaternary-N. When combining the synergic effect of transitional metal-based nanoparticles with the controlled N-doped carbon matrix, the noble metal-free catalysts might be further developed as promising candidates to replace the state-of-the-art $\mathrm{Pt} / \mathrm{C}$ in fuel cell and metal-air batteries.

Supplementary Materials: The following are available online at http://www.mdpi.com/2079-4991/10/2/223/s1. Table S1: Atomic percent of A/Co, Q/Co, Q-A/Co from EDS, Figure S1. (a-c) CV curves of synthesized catalysts with scan rate $10-0 \mathrm{mV} / \mathrm{s}$ in $0.1 \mathrm{M} \mathrm{KOH}$, (d) Current density differences plot with scan rate. $\Delta \mathrm{J}$ is current differences between $\mathrm{J} a$ (anodic current) and $\mathrm{J} c$ (cathodic current) at potential $0.5 \mathrm{~V}$ vs. RHE which is non faradaic region; Figure S2. (a) Electron transfer number and, (b) peroxide yielding of Q-A/Co, A/Co, Q/Co.

Author Contributions: S.K. performed carbon characterization and electrochemical data; H.P. and O.L.L. helped in the data analysis of electrochemistry, discussion of the results and wrote the manuscript. All authors discussed the results and contributed to manuscript preparation. All authors have read and agreed to the published version of the manuscript.

Funding: This work was supported by Basic Science Research Program through the National Research Foundation of Korea (NRF) grant funded by the Korea government (MSIP) through GCRC-SOP (No. 2011-0030013).

Conflicts of Interest: The authors declare no conflict of interest.

\section{References}

1. Fan, W.; Li, Z.; You, C.; Zong, X.; Tian, X.; Miao, S.; Shu, T.; Li, C.; Liao, S. Binary Fe, Cu-doped bamboo-like carbon nanotubes as efficient catalyst for the oxygen reduction reaction. Nano Energy 2017, 37, $187-194$. [CrossRef]

2. Du, J.; Cheng, F.; Zhang, T.; Chen, J. M(Salen)-derived Nitrogen-doped M/C(M = Fe, Co, Ni) Porous Nanocomposites for electrocatalytic Oxygen Reduction. Sci. Rep. 2014, 4, 4386. [CrossRef] [PubMed]

3. Peng, H.; Liu, F.; Lut, X.; Liao, S.; You, C.; Tian, X.; Nan, H.; Luo, F.; Song, H.; Fu, Z.; et al. Effect of Transition Metals on the structure and Performance of the Doped Carbon Catalysts Derived from Polyaniline and Melamine for ORR Application. ACS Catal. 2014, 5, 3797-3805. [CrossRef]

4. Ratso, S.; Kruusenberg, I.; Kaarik, M.; Kook, M.; Puust, L.; Saar, R.; Leis, G.; Tammeveski, K. Highly efficient transition metal and nitrogen co-doped carbide-derived carbon electrocatalysts for anion exvhange membrane fuel cells. J. Power Sources 2018, 375, 233-243. [CrossRef]

5. Martinez, U.; Babu, S.K.; Holby, E.F.; Chung, H.T.; Yin, X.; Zelenay, P. Progress in the Development of Fe-Based PGM-free Electrocatalysts for the Oxygen Reduction Reaction. Adv. Mater. 2019, 31, 1806545. [CrossRef]

6. Cai, S.; Meng, Z.; Tang, H.; Wang, Y.; Tsiakaras, P. 3D Co-N-doped hollow carbon sphere as excellent bifunctional electrocatalysts for oxygen reduction reaction and oxygen evolution reaction. Appl. Catal. B Environ. 2017, 217, 477-484. [CrossRef]

7. Fu, G.; Liu, Y.; Chen, Y.; Tang, Y.; Goodenough, J.B.; Lee, J.M. Robust N-doped carbon aerogels strongly coupled with iron-cobalt particles as efficient bifunctional catalysts for rechargeable Zn-air batteries. Nanoscale 2018, 10, 19937. [CrossRef] 
8. Ghanbarlou, H.; Rowshanzair, S.; Kazeminasab, B.; Parnian, M.J. Non-precious metal nanoparticles supported on nitrogen0doped graphene as a promising catalyst for oxygen reduction reaction: Synthesis, characterization and electrocatalytic performance. J. Power Sources 2015, 273, 981-989. [CrossRef]

9. Sharma, M.; Jang, J.H.; Shin, D.Y.; Kwon, J.A.; Lim, D.H.; Choi, D.; Sung, H.; Jang, J.H.; Lee, S.Y.; Lee, K.Y.; et al. Work function-tailored graphene via transition metal encapsulation as a highly active and durable catalyst for the oxygen reduction reaction. Energy Environ. Sci. 2019, 12, 2200-2211. [CrossRef]

10. Guo, H.; Feng, Q.; Zhu, J.; Xu, J.; Li, Q.; Liu, S.; Xu, K.; Zhang, C.; Liu, T. Cobalt nanoparticle-embedded nitrogen-doped carbon/carbon nanotube frameworks derived from a metal-organic framework for tri-functional ORR, OER and HER electrocatalysis. J. Mater. Chem. A 2019, 7, 3664. [CrossRef]

11. Zhang, C.L.; Lu, B.R.; Cao, F.H.; Wu, Z.Y.; Zhang, W.; Cong, H.P.; Yu, S.H. Electrospun metal-organic framework nanoparticle fibers and their derived electrocatalysts for oxygen reduction reaction. Nano Energy 2019, 55, 226-233. [CrossRef]

12. Guo, B.; Ma, R.; Li, Z.; Guo, S.; Luo, J.; Yang, M.; Liu, Q.; Thomas, T.; Wang, J. Hierarchical N-Doped Porous Carbons for Zn-Air Batteries and Supercapacitors. Nano-Micro Lett. 2020, 12, 20. [CrossRef]

13. Khan, Z.; Park, S.O.; Yang, J.; Park, S.; Shanker, R.; Song, H.K.; Kim, Y.; Kwak, S.K.; Ko, H. Binary N,S-doped carbon nanospheres from bio-inspired artificial melanosomes: A route to efficient air electrodes for seawater batteries. J. Mater. Chem. A 2018, 6, 24459. [CrossRef]

14. Zhao, S.; Wang, D.W.; Amal, R.; Dai, L. Carbon-Based Metal-Free Catalyst for Key Reactions Involved in Energy Conversion and Storage. Adv. Mater. 2019, 31, 1801526. [CrossRef] [PubMed]

15. Guo, D.; Shibuya, R.; Akiba, C.; Saji, S.; Kondo, T.; Nakamura, J. Active sites of nitrogen-doped carbon materials for oxygen reduction reaction clarified using model catalysts. Science 2016, 351, 6271. [CrossRef] [PubMed]

16. Yan, P.; Liu, J.; Yuan, S.; Liu, Y.; Cen, W.; Chen, Y. The promotion effects of graphitic and pyridinic N combinational doping on graphene for ORR. Appl. Surf. Sci. 2018, 445, 398-403. [CrossRef]

17. Wu, G.; Santandreu, A.; Kellogg, W.; Gupta, S.; Ogoke, O.; Zhang, H.; Wang, H.L.; Dai, L. Carbon nanocomposite catalysts for oxygen reduction and evolution reactions: From nitrogen doping to transition-metal addition. Nano Energy 2016, 29, 83-110. [CrossRef]

18. Dumont, J.H.; Martinez, U.; Artyushkove, K.; Purdy, G.M.; Dattelbaum, A.M.; Zelenay, P.; Mohite, A.; Atanassov, P.; Gupta, G. Nitrogen-Doped Graphene Oxide Electrocatalysts for the Oxygen Reduction Reaction. ACS Appl. Nano Mater. 2019, 2, 1675-16785. [CrossRef]

19. Vilaplana, A.F.; Herrero, E. Understanding the chemisorption-based activation mechanism of the oxygen reduction reaction on nitrogen-doped graphitic materials. Electrochim. Acta 2016, 204, 245-254. [CrossRef]

20. Hu, F.; Yang, H.; Wang, C.; Zhang, Y.; Lu, H.; Wang, Q. Co-N-Doped Mesoporous Carbon Hollow Spheres as Highly Efficient Electrocatalysts for Oxygen Reduction Reaction. Small 2017, 13, 1602507. [CrossRef]

21. Ma, X.; Zhao, X.; Huang, J.; Sun, L.; Li, Q.; Yang, X. Fine Co Nanoparticles Encapsulated in a N-Doped Porous Carbon Matrix with Superfical N-doped Porous Carbon nanofibers for Efficient Oxygen Reduction. ACS Appl. Mater. Interfaces 2017, 9, 21747-21755. [CrossRef] [PubMed]

22. Liu, S.; Wang, Z.; Zhou, S.; Yu, F.; Yu, M.; Chiang, C.Y.; Zhou, W.; Zhao, J.; Qiu, J. Metal-Organic-Framework-Derived Hybrid Carbon Nanocages as a Bifunctional Electrocatalyst for Oxygen Reduction and Evolution. Adv. Mater. 2017, 29, 1700874. [CrossRef] [PubMed]

23. Li, R.; Wang, X.; Dong, Y.; Pan, X.; Liu, X.; Zhao, Z.; Qiu, J. Nitrogen-doped carbon nanotubes decorated with cobalt nanoparticles derived from zeolitic imidazolate framework-67 for highly efficient oxygen reduction reaction electrocatalyst. Carbon 2018, 132, 580-588. [CrossRef]

24. Shu, J.; Niu, Q.; Wang, N.; Nie, J.; Ma, G. Alginate derived Co/N doped hierarchical porous carbon microspheres for efficient oxygen reduction reaction. Appl. Surf. Sci. 2019, 485, 520-528. [CrossRef]

25. Sun, M.; Wu, X.; Deng, X.; Zhang, W.; Xie, Z.; Huang, Q.; Huang, B. Synthesis of pyridinic-N doped carbon nanofibers and its electro-catalytic activity for oxygen reduction reaction. Mater. Lett. 2018, 220, 313-316. [CrossRef]

26. Muthuswamy, N.; Buan, M.E.M.; Walmsley, J.C.; Ronning, M. Evaluation of ORR active sites in nitrogen-doped carbon nanofibers by $\mathrm{KOH}$ post treatment. Catalysis Today 2018, 301, 11-16. [CrossRef]

27. Zhang, C.; Hao, R.; Liao, H.; Hou, Y. Synthesis of amino-functionalized graphene as metal-free catalyst and exploration of the roles of various nitrogen stated in oxygen reduction reaction. Nano Energy 2013, 2, 88-97. [CrossRef] 
28. Li, O.L.; China, S.; Wada, Y.; Panomsuwan, G.; Ishizaki, T. synthesis of graphitic -N and amino-N in nitrogen-doped carbon via a solution plasma process and exploration of their synergic effect for advanced oxygen reduction reaction. J. Mater. Chem. A 2017, 5, 2073. [CrossRef]

29. Mamtani, K.; Jain, D.; Dogu, D.; Gustin, V.; Gunduz, S.; Co, A.C.; Ozkan, U.S. Insights into oxygen reduction reaction (ORR) and oxygen evolution reaction (OER) active sites for nitrogen-doped carbon nanostructures (CNx) in acidic media. Appl. Catal. B Environ. 2018, 220, 88-97. [CrossRef]

30. Singh, S.K.; Takeyasu, K.; Nakamura, J. Active sites and Mechanism of Oxygen Reduction Reaction Electrocatalysis on Nitrogen-Doped Carbon Materials. Adv. Mater. 2019, 31, 1804297. [CrossRef]

31. Chatterjee, K.; Ashokkumar, M.; gullapalli, H.; Gong, Y.; Vajtal, R.; Thanikaivelan, P.; Ajayan, P.M. Nitrogen-rich carbon nano-onions for oxygen reduction reaction. Carbon 2018, 130, 645-651. [CrossRef]

32. Li, Z.; Gao, Q.; Qian, W.; Tian, W.; Zhang, H.; Zhang, Q.; Liu, Z. Ultrahigh Oxygen Reduction Reaction Electrocatalytic Activity and Stability over Hierarchical Nanoporous N-doped Carbon. Sci. Rep. 2018, 8, 2863. [CrossRef] [PubMed]

33. Lv, Q.; Si, W.; He, J.; Sun, L.; Zhang, C.; Wang, N.; Yang, Z.; Li, X.; Wang, X.; Deng, W.; et al. Selectively nitrogen-doped carbon materials as superior Metal-free catalysts for oxygen reduction. Nat. Commun. 2018, 9, 3376. [CrossRef] [PubMed]

34. Yang, H.B.; Miao, J.; Hung, S.F.; Chen, J.; Tao, H.B.; Wang, X.; Zhang, L.; Chen, R.; Gao, J.; Chen, H.M.; et al. Identification of catalytic sites for oxygen reduction and oxygen evolution in $\mathrm{N}$-doped graphene materials: Development of highly efficient metal-free bifunctional electrocatalyst. Sci. Adv. 2016, 2, 1501122. [CrossRef] [PubMed]

35. Wang, N.; Lu, B.; Li, L.; Niu, W.; Tang, Z.; Kang, X.; Chen, S. Graphitic Nitrogen is responsible for oxygen electroreduction on Nitrogen-Doped Carbons in Alkaline Electrolytes: Insights from Activity Attenuation Studies and Theoretical Calculations. ACS Catal. 2018, 8, 6827-6836. [CrossRef]

36. Ning, X.; Li, Y.; Ming, J.; Wang, Q.; Wang, H.; Cao, Y.; Peng, F.; Yang, Y.; Yu, H. Electronic synergism of pyridinic- and graphitic- nitrogen on N-doped carbons for the oxygen reduction reaction. Chem. Sci. 2019, 10, 1589. [CrossRef] [PubMed]

37. Kim, D.W.; Li, O.L.; Pootawang, P.; Saito, N. Solution plasma synthesis process of tungsten carbide on $\mathrm{N}$-doped carbon nanocomposite with enhanced catalytic ORR activity and durability. RSC Adv. 2014, 4, 16813. [CrossRef]

38. Panomsuwan, G.; Saito, N.; Ishizaki, T. Nitrogen-doped carbon nanoparticles derived from acrylonitrile plasma for electrochemical oxygen reduction. Phys. Chem. Chem. Phys. 2015, 17, 6227. [CrossRef]

39. Panomsuwan, G.; China, S.; Kaneko, Y.; Saito, N.; Ishizaki, T. In situ solution plasma synthesis of nitrogen-doped carbon nanoparticles as metal-free electrocatalysts for the oxygen reduction reaction. J. Mater. Chem. A 2014, 2, 18677. [CrossRef]

40. Panomsuwan, G.; Saito, N.; Ishizaki, T. Simple one-step synthesis of fluorine-doped carbon nanoparticles as potential alternative metal-free electrocatalysts for oxygen reduction reaction. J. Mater. Chem. A 2015, 3, 9972. [CrossRef]

41. Panomsuwan, G.; Saito, N.; Ishizaki, T. Electrocatalytic oxygen reduction activity of boron-doped carbon nanoparticles synthesized via solution plasma process. Electrochem. Commun. 2015, 59, 81-85. [CrossRef]

42. Li, O.L.; Wada, Y.; Kaneko, A.; Lee, H.; Ishizaki, T. Oxygen Reduction Reaction Activity of Thermally Tailored Nitrogen-Doped Carbon Electrocatalysts Prepared through Plasma Synthesis. ChemElectroChem 2018, 5, 1995-2001. [CrossRef]

43. Li, O.L.; prabaka, K.; Kaneko, A.; Park, H.; Ishizaki, T. Exploration of Lewis basicity and oxygen reduction reaction activity activity in plasma-tailored nitrogen-doped carbon electrocatalysts. Catal. Today 2019, 337, 102-109. [CrossRef]

44. Li, O.L.; Shi, Z.; Lee, H.; Ishizaki, T. Enhanced Electrocatalytic Stability of Platinum Nanoparticles Supported on Sulfur-Doped Carbon using in-situ solution plasma. Sci. Rep. 2019, 9, 12704. [CrossRef]

45. Zhou, R.; Zheng, Y.; Jaroniec, M.; Qiao, S.Z. Determination of the Electron Transfer Number for the Oxygen Reduction Reaction: From Theory to Experiment. ACS Catal. 2016, 6, 4720-4728. [CrossRef]

46. Kang, J.; Li, O.L.; Saito, N. Synthesis of structure-controlled carbon nano spheres by solution plasma process. Carbon 2013, 60, 292-298. [CrossRef]

47. Ferrero, G.A.; Fuertes, A.B.; Sevilla, M.; Titrici, M.M. Efficient metal-free N-doped mesoporous carbon catalyst for ORR by a template-free approach. Carbon 2016, 106, 179-187. [CrossRef] 
48. An, L.; Jiang, N.; Li, B.; Hua, S.; Fu, Y.; Liu, J.; Hao, W.; Xia, D.; Sun, Z. A highly active and durable iron/cobalt alloy catalyst encapsulated in $\mathrm{N}$-doped graphitic carbon nanotubes for oxygen reduction reaction by a nanofibrous dicyandiamide template. J. Mater. Chem. A 2018, 6, 5962. [CrossRef]

49. Guan, B.Y.; Yu, L.; Lou, X.W. Formation of Single-Holed Cobalt/N-Doped Carbon Hollow Particles with Enhanced Electrocatalytic Activity toward Oxygen Reduction Reaction in Alkaline Media. Adv. Sci. 2017, 4, 1700247. [CrossRef]

50. Lai, L.; Potts, J.R.; Zhan, D.; Wang, L.; Poh, C.K.; Tang, C.; Gong, H.; Shen, Z.; Lin, J.; Ruoff, R.S. Exploration of the active center structure of nitrogen-doped graphene-based catalysts for oxygen reduction reaction. Energy Environ. Sci. 2012, 5, 7936. [CrossRef]

(C) 2020 by the authors. Licensee MDPI, Basel, Switzerland. This article is an open access article distributed under the terms and conditions of the Creative Commons Attribution (CC BY) license (http://creativecommons.org/licenses/by/4.0/). 